\title{
INVENTARISASI JENIS KATAK (RANIDAE) SEBAGAI KOMODITI EKSPOR DI SUMATERA BARAT
}

\author{
Wince Hendri* \\ Program Studi Pendidikan Biologi \\ Fakultas Keguruan dan Ilmu Pendidikan Universitas Bung Hatta
}

(Diterima Oktober 2015, Disetujui Desember 2015)

\begin{abstract}
This research aims to inventory and analyze frogs diversity (Ranidae) which hunted for trading as an export commodity in West Sumatra. The study was conducted in Sijunjung, Ujung Gading (Pasaman), Mentawai (Central Siberut), and Tarusan (Painan) by direct capture method. Results showed species which often captured, and sold were Fejervarya limnocharis was found in Ujung Gading (Pasaman), Sijunjung and Painan; Limnonectes blythii was found in Sijunjung, Pasaman, Mentawai, Rana erythrea was found in Pasaman and Painan. Refer to research that has been done seen large size frog species such as Limnonectes blythii, and Limnonectes sp. were seldomly found, but small size frog species such as Fejervarya limnocharis was found in large numbers. This research concluded that species diversity of frogs (ranidae) were found in West Sumatra has a different distribution pattern in different regions. This study needs to be followed by more in-depth research to the genetic diversity considering some very rare species and to analyze the phylogenetic relationships among and within spseies was found.
\end{abstract}

Keywords: Inventaritation,Biodiversity, West Sumatra

\begin{abstract}
ABSTRAK
Penelitian ini bertujuan untuk menginventarisasi dan menganalisis keanekaragaman jenis katak (Ranidae) yang ditangkap untuk diperjualbelikan penduduk di daerah Sumatera Barat sebagai komoditi ekspor. Penelitian dilakukan di daerah Sijunjung, Ujung Gading (Pasaman), Mentawai (Siberut Tengah) dan Tarusan (Painan) dengan metode penangkapan secara langsung di lapangan. Hasil penelitian menunjukkan jenis katak yang sering ditangkap dan diperjualbelikan adalah jenis Fejervarya limnocharis ditemukan pada lokasi Ujung Gading (Pasaman), Sijunjung dan Painan; Limnonectes blythii ditemukan di Sijunjung, Pasaman, Mentawai, Rana erythraeaditemukaan di Pasaman dan Painan, Rana chalconata dan Limnonectes sp. Dari penelitian yang telah dilakukan terlihat beberapa jenis katak berukuran besar sepeti Limnonectes blythiidan. Limnonectes sp. jarang ditemukan, tetapi katak berukuran kecil Fejervarya limnocharis ditemukan dalam jumlah yang banyak. Dari penelitian ini dapat disimpulkan bahwa keanekaragaman jenis katak Ranidae yang ditangkap di Sumatera Barat
\end{abstract}

*Penulis korespondensi : Wince Hendri. Prodi Pendidikan Biologi FKIP Universitas Bung Hatta 
mempunyai gambaran spesies yang berbeda pada kawasana daerah yang berbeda. Penelitian ini perlu dilanjutkan dengan penelitian lebih mendalam kepada keanekaragaman genetik mengingat beberapa jenis sangat jarang ditemukan serta menganalisis hubungan filogenetik diantara dan di dalam spseies itu ditemukan.

Katakunci: filogenetik, inventarisasi, dan kenekaragaman

\section{PENDAHULUAN}

Amfibia adalah vertebrata pertama yang beralih dari kehidupan di air ke kehidupan di darat karena tidak dapat beradaptasi secara penuh dengan lingkungan daratan maka hewan ini hidup di antara lingkungan berair dan daratan, mempunyai kulit basah, berkelenjar, lembut, tanpa rambut, bulu dan sisik. Ampihibia tergolong hewan berdarah dingin dengan suhu yang bervariasi tergantung pada keadaan lingkungan (poikilotermal-ektotermal) (van Kampen, 1923; Storer dan Usinger, 1968).

Pada umumnya Amfibia bersifat tidak khusus dalam pemilihan makanannya. Hal ini merupakan salah satu penunjang kesuksesan dalam hal melangsungkan kehidupannya di alam bebas. Dari tingkah laku makan dan kemampuan memangsa hewan apa saja yang dapat ditelannya sesuai dengan habitatnya di pinggir-pinggir sungai pada umumnya, memungkinkan katak sebagai pengontrol hama tanaman secara biologis.

Ukuran bobot badan katak jantan dewasa yang pernah ditemukan mencapai 900 g sedangkan katak betina mencaai 1100 g. panjang badang (dari mulut ke dubur) katak jantan dewasa dpat mencapai $200 \mathrm{~mm}$ dan betina $220 \mathrm{~mm}$ (Sugiri dan Soenarjo, 1980). Aktifitas mencari makan katak umumnya berlangsung pada malam hari apabila kelembaban tinggi. Perpindahan dan perkawinan biasanya dilakukan apabila hujan mulai turun.

Beberapa penduduk di Sumatera Barat menangkap beberapa jenis katakdari alam diperjualbelikan dan untuk diekspor sebagai sumber pendapatan.. Akhir-akhir ini jenis katak tersebut sudah jarang ditemukan pada habitatnya karena populasinya menurun. Turunnya populasi juga disebabkan oleh penggunaan pestisida yang dapat mematikan kecebong dan anak-anak katak yang sedang tumbuh serta karena kerusakan habitat. 
Pada masa yang akan datang, tekanan terhadap populasi katak akan terus berlanjut dan bukan tidak mungkin pada suatu saat spesies yang ditangkap ini akan punah. Kajian konservasi sebagai upaya dan sarana perlindungan di negara lain sudah banyak dilakukan, karena dari segi kepadatannya terlihat penurunan populasi, namun di Indonesia dengan tingkat keanekaragaman yang tinggi belum ada amphibia yang dilindungi. Hal ini tentu memerlukan perhatian besar, terutama pada spesies endemik, langka dan mempunyai nilai ekonomi tinggi bagi penduduk.

Pandangan umum menyatakan keanekaragaman fauna yang paling tinggi ada di hutan tropik. Demikian pula halnya mengenai keanekaragaman hewan Amphibia yang tertinggi ada di daerah tropik. Di hutan hujan tropik terdapat hubungan komunitas yang kompleks. Hubungan tersebut akan lebih menjadi khusus (terspesialisasi) dengan adanya dukungan masalah relung (niche) dan stenofagi interspesies yang tersegrasi. Sehingga hal tersebut menyebabkan keanekaragaman (kekayaan) spesies komunitas meningkat.

Keanekaragaman hayati merupakan ciri khas suatu daerah yang menyangkut keragaman di dalam dan di antara oganisme hidup, kumpulan organisme, komunitas biotik dan proses biotik yang masih bersifat alamiah maupun yang sudah diubah oleh manusia. Keanekaragaman hayati dapat diukur dari level genetik beserta identitasnya, jumlah spesies, kumpulan spesies, komunitas biotik, proses biotik dan jumlah (seperti kelimpahan, biomassa, penutupan dan laju) serta struktur dari level-level tersebut. Iskandar dan Erdelen (2004), melaporkan bahwa Indonesia, sebagai salah satu pusat keanekaragaman yang terbesar di dunia, baik dari segi kekayaan alam jenisnya maupun dari segi tingkat endemisitasnya. $16 \%$ dari amfibi dan reptil dunia terdapat di Indonesia, dengan jumlah lebih dari 1100 jenis.

Keberadaan spesies-spesies dan kelimpahan populasi amphibia lebih banyak terdapat pada daerah-daerah yang kelembaban udaranya cukup tinggi seperti, misalnya, dekat suatu perairan. Selain itu, ketinggian suatu daerah juga berpengaruh terhadap keanekaragaman spesies dari amphibia. Hubungan perkerabatan evolusioner atau filogenetik di antara famili Amphibia merupakan 
suatu yang sangat mendasar untuk menginterpretasikan biogeografinya dan sangat berarti dalam menyusun klasifikasinya.

Penelitian terhadap jenis katak pada umumnya di Sumatera Barat sudah banyak dilakukan baik aspek taksonomi, evolusi, ekologi maupun genetika terhadap jenis tertentu. Seperti yang telah dilakukan oleh Djong, (2003); Djong, et al (2007), Djong (2010); Inger and Iskandar (2009), namun jenis-jenis yang ditangkap, diekspor dan mempunyai nilai ekonomis serta analisisis keanekaragaman jenis katakbelum diketahui dengan jelas.

Berdasarkan hal tersebut di atas untuk meningkatkan ketersediaan katak, serta menjamin kebutuhan penduduk yang berkesinambungan, maka diperlukan informasi jenis katak apa saja yang ditangkap untuk diperjualbelikan penduduk di daerah Sumatera Barat dengan tujuan untuk:

1. Menginventarisasi jenis katak yang ditangkap dan diperjualbelikan penduduk di daerah Sumatera Barat.

2. Menganalisis keberadaan katak yang ditangkap yang diperjualbelikan penduduk di daerah Sumatera Barat.

Dari penelitian ini diharapkan informasi mengenai jenis katak yang ditangkap di daerah Sumatera Barat dalam upaya meningkatkan perdagangan katak dan sebagai strategi pelestarian ataupun usaha domestifikasi katak dimasa yang akan datang.

\section{METODE PENELITIAN}

Penelitian ini dilakukan di daerah Sumatera Barat pada lokasi di daerah Sijunjung, Ujung Gading (Pasaman Barat), Siberut Tengah (Mentawai) dan Tarusan (Pesisir Selatan) dengan metode jelajah. Katak yang didapatkan diidentifikasi dan dikoleksi di laboratorium Biologi Universitas Bung Hatta.Katak-katak family Ranidae yang didapatkan dipelihara dan diidentifikasi untuk menetapkan karakteristik dan jenis untuk keperluan taksonomi. Alat-alat yang digunakan adalah lampu senter, ember plastik, karung plastik, kantung plastik, alat seksi, spuit $5 \mathrm{ml}, 2 \mathrm{ml}$, dan spuit $1 \mathrm{ml}$, cawan petri, gelas ukur $10 \mathrm{ml}$, 
gelas ukur $100 \mathrm{ml}$, pipet ukur, tabung reaksi, pipet kecil, termos es, sarung tangan, loup, dan alat potret.

Sampel katak ditangkap dari pinggir sungai dan semak sekitarnya pada malam hari dengan bantuan kolektor di lapangan, katak yang didapatkan dimasukkan dalam kantong plastik, diberi label dan di bawa ke laboratorium untuk diidentifikasi.

\section{HASIL DAN PEMBAHASAN}

Dari penelitian yang telah dilakukan didapatkan 5 jenis amfibia famili Ranidae, yaitu Fejervarya limnocharis, Rana calconata, Rana erythraea, Limnonectes blythii dan, Limnonectes sp. Jenis-jenis katak yang dijumpai kategori melimpah adalah Fejervarya limnocharis,Ranaerythraea, Rana chalconata. Sedangkan Rana bylthi dijumpai dalam jumlah yang sangat sedikit.Kerapatan jenis yang ditemukan dapat dilihat padatabel di bawah ini:

Tabel 1: Keragaman jenis dan jumlah spesies katak yang ditemukan pada tiap lokasi penangkapan di Sumatera Barat

\begin{tabular}{|c|c|c|c|c|c|}
\hline \multirow[b]{2}{*}{ No. } & \multirow[b]{2}{*}{ Jenis } & \multicolumn{4}{|c|}{ Lokasi } \\
\hline & & SJJ & $\mathrm{PB}$ & MT & $\begin{array}{c}\text { PS } \\
\text { S }\end{array}$ \\
\hline 1 & $\begin{array}{l}\text { Fejervarya } \\
\text { limnocharis }\end{array}$ & 6 & 18 & - & 4 \\
\hline 2 & $\begin{array}{l}\text { Limnonectes } \\
\text { blythii }\end{array}$ & 2 & 2 & 2 & - \\
\hline 3 & Rana erythraea & - & 5 & - & 2 \\
\hline 4 & $\begin{array}{l}\text { Rana } \\
\text { chalconata }\end{array}$ & - & 3 & - & 5 \\
\hline 5 & Limnonectes sp & - & - & 2 & - \\
\hline
\end{tabular}

\section{Fejervarya limnocharis}

Klasifikasi :

$\begin{array}{ll}\text { Kingdom } & \text { : Animalia } \\ \text { Filum } & : \text { Chordata } \\ \text { Kelas } & : \text { Amphibia } \\ \text { Ordo } & : \text { Anura } \\ \text { Famili } & : \text { Ranidae } \\ \text { Genus } & \text { : Fejervarya }\end{array}$


Species $\quad$ : Fejervarya limnocharis

Jenis katak ini ditemukan di lokasi Pasaman Barat (Ujung Gading)dan Pesisir Selatan (Tarusan). Dijumpai di sawah penduduk dan pinggiran perairan yang banyak terdapat tanaman air, duduk di atas daun-daun rumputan sekitar di atas permukaan.(Perbaiki redaksional, awal kalimat tidak umum didahului oleh kata kerja). Kadang-kadang jenis ini dijumpai pada areal daratan sekitar 1 meter dari tepi perairan. Jenis ini ditangkap dan dijual oleh penduduk. Katak ini dikenal dengan Katak Sawah dan dagingnya umum dikonsumsi manusia.Jari kaki belakang setengah selaput pada ruas terakhir, memiliki sepasang bintil metatarsal, tekstur kulit berkerut tertutup oleh bintil-bintil panjang yang tipis. Tympanum terlihat jelas. Punggung berwarna coklat dengan bercak gelap dengan corak bentuk huruf $\mathrm{W}$ atau $\mathrm{U}$ di antara bahu. seperti lumpur dengan bercak-bercak yang lebih gelap yang kurang jelas tetapi simetris. Perut berwarna putih, pada bagian bagian punggung terdapat garis vertebral keputihan. Panjang tubuh $30-50$ mm.(Gambar 1)

Tekstur kulit berkerut, tertutup oleh bintil-bintil tipis yang biasanya memanjang, pararel dengan sumbu tubuh. Warna kulit kotor seperti lumpur dengan bercak-bercak yang lebih gelap yang kurang jelas tetapi simetris,

\section{Limnonectes Blythii}

Klasifikasi ilmiah:

$\begin{array}{ll}\text { Kingdom } & : \text { Animalia } \\ \text { Phylum } & : \text { Chordata } \\ \text { Class } & : \text { Amphibia } \\ \text { Ordo } & : \text { Anura } \\ \text { Famili } & : \text { Ranidae } \\ \text { Genus } & : \text { Limnonectes } \\ \text { Spesies } & : \text { Limnonectes blythii }\end{array}$

Jenis katak ini ditemukan di Sijunjung, Pasaman Barat dan Mentawai, tetapi tidak ditemukan di Painan. Kerap dijumpai pada bagian tepi anak air perairan, 
duduk di atas rumputan sekitar $10 \mathrm{~cm}$ di atas permukaan, walaupun dalam jumlah yang sedikit. Kadang-kadang jenis ini dijumpai pada areal daratan sekitar 1 meter dari tepi perairan. Ukuran tubuh lebih besar. Kepala pipih, moncong halus dan bentuk triangular. Ujung moncong dapat rincing atau tumpul, cantus rostalis tak jelas. Lore agak cekung, Lore dan pipi miring kebawah, antara mata dan tulang rahang atas terdapat alur sempit. Lipatan supra timpani yang membujur dari bagian belakang mata melalui bagian atas gendang telinga menuju ke aksila dalam bentuk lengkungan. Di antara bagian belakang kedua matanya terdapat lekuk yang tak jelas. Membran timpani terlihat jelas. Pada kelopak mata atas bagian belakang bintil-bintil. Pada rahang bagian depan terdapat satu pasang penonjolan tulang (apofisis), dengan lidah oval yang tebal dan bercabang dua (Gambar 5).

Pada tungkai depan, ujung jari berbentuk bulatan kecil, secara berurutan jari ketiga relatif lebih panjang dari jari pertama, keempat dan jari kedua. Pada sisi medial jari kedua dan ketiga terdapat rigi dermal. rigi dermal sisi lateral jari kedua tidak tumbuh dengan subur, sedangkan pada sisi lateral jari ketiga mempunyai rigi tersebut. Tuberkel metakarpal besar dan oval. Tungkai belakang berselaput renang penuh, ujung jari-jari berakhir dengan cakram kecil. Selaput renang antara jari kaki keempat dan kelima berpadanan tinggi dengan subartikular ketiga dan agak cekung. Secara berurutan jari kaki keempat lebih panjang dari pada jari ketiga, kelima, kedua dan jari pertama. Sisi lateral jari kelima dan sisi medial tarsal lipatan kulit (lipatan tarsal) yang tidak jelas atau tidak ada. Tuberkel tarsal sebelah medial besar dan memanjang, sedangkan tuberkel subatikular berbentuk bulat atau lonjong. Kulit halus, warna kulit pada bagian atas kepala dan punggung coklat abu-abu terang, kelabu hitam sampai hitam dengan bercak hitam maupun coklat. garis loreal yang membujur dari hidung sampai mata tidak pernah dijumpai. Garis di antara kedua mata tidak jelas. Tanda huruf $\mathrm{W}$ pada bagian dorsal yang terdapat diantara kedua tungkai depan kadang-kadang terlihat dengan jelas, kadang-kadang tidak jelas. garis punggung yang membujur dari bagian antara telinga sampai dubur tidak pernah dijumpai. Permukaan ventral kepala berpigmen. Bibir sering dengan bercak gelap atau aris vertikal. 
Pada bagian lengan bagian atas kaki depan terdapat lorek tak teratur. Pada bagian dorsal paha terdapat lorek yang tak teratur, sedangkan di bagian belakang terdapat totol yang tak teratur. Pada betis dan tapak tungkai belakang terdapat lorek. Permukaan bawah tungkai belakang berwarna kuning pucat atau orange pucat seharusnya atau dengan bercak coklat. hewan jantan tidak mempunyai kantung suara.

\section{Rana erythraea}

Klasifikasi ilmiah:

$\begin{array}{ll}\text { Kingdom } & : \text { Animalia } \\ \text { Phylum } & : \text { Chordata } \\ \text { Class } & : \text { Amphibia } \\ \text { Ordo } & : \text { Anura } \\ \text { Famili } & : \text { Ranidae } \\ \text { Genus } & : \text { Rana } \\ \text { Spesies } & : \text { R. erythraea }\end{array}$

Jenis katak ini dijumpai pada tipe habitat kolam dengan bagian tepi berdekatan dengan persawahan. Kebiasaan pada habitat yang disukainya adalah berdiam diri dengan memendamkan badannya ke dalam air, hanya matanya berada di permukaan air. Warna kulit bagian dorsal kehijauan dan lipatan dorsolateral berwarna kekuningan dengan pita berwarna kehitaman. hijau lumut atau hijau muda di punggungnya. Sepasang lipatan dorsolateral yang jelas, besar, berwarnakekuningan dan kadang-kadang disertai dengan garis hitam, terdapat di kiri kanan punggung. Tangan dan kaki berwarna kuning coklat muda, dengan loreng-loreng terutama pada paha. Sisi bawah tubuh berwarna putih. Kulit licin dan halus. Ukuran sekitar 45-75 mm.Tangan dengan ujung jari melebar serupa piringan yang meruncing, yang terbesar sekitarse tengah diameter timpanum (gendang telinga).

Piringan pada jari kaki lebih kecil. Selaput renang mencapai pangkal piringan di jari-jari kaki, kecuali pada jari keempat yang memiliki dua ruas bebas dari selaput. Terdapat sekurangnya satu bintil metatarsal di kaki, yakni di sisi dalam (Gambar 2). 


\section{Rana chalconata}

Klasifikasi ilmiah:

$\begin{array}{ll}\text { Kingdom } & : \text { Animalia } \\ \text { Phylum } & : \text { Chordata } \\ \text { Class } & : \text { Amphibia } \\ \text { Ordo } & : \text { Anura } \\ \text { Famili } & : \text { Ranidae } \\ \text { Genus } & : \text { Rana } \\ \text { Spesies } & : \text { R.chalconota }\end{array}$

Warna tubuh coklat muda berbintik hitam. Garis coklat tua memanjang pada bagian samrping tubuh, mulai moncong sampai pangkal kaki belakang. Kulit halus dan licin. Panjang tubuh katak katak $38 \mathrm{~mm} n \mathrm{nn}-60 \mathrm{~mm}$. Putaran gelap tempat di belakang (kecuali di dua), bintik dari melanophores pada permukaan ventral kaki, tenggorokan keputihan, dengan bintik gelap. Vomerine gigi berjarak satu sama lain. Jari kaki berjumlah empat sepenuhnya berselaput untuk distal subarticular tuberkulum; tuberkulum metatarsal luar ditinggikan. Jantan dengan bantalan perkawinan keputihan pada jari pertama; vokal kantung bukaan di sudutsudut lantai mulut; spinules keputihan pada butiran dari dorsum.

Pada jantan memiliki spinules dikelopak mata bagian atas. Jantan dalam sampel ini 30-40 $\mathrm{mm}$, tetapi betina jauh lebih kecil $(45-65 \mathrm{~mm})$. Katak ini dengan diameter lebih kecil timpanum relatif pada jantan (Gambar 3).

\section{Limnonectes $s p$}

Klasifikasi ilmiah:

$\begin{array}{ll}\text { Kingdom } & : \text { Animalia } \\ \text { Phylum } & : \text { Chordata } \\ \text { Class } & : \text { Amphibia } \\ \text { Ordo } & : \text { Anura } \\ \text { Famili } & : \text { Ranidae } \\ \text { Genus } & : \text { Limnonectes } \\ \text { Spesies } & : \text { Limnonectes sp1 }\end{array}$


Jenis katak ini ditemukan di Pasaman dan Painan. Dijumpai pada bagian tepi anak air perairan dengan cirri-iri hampir mirip dengan Limnonectes blythii. Kepala pipih, moncong halus dan bentuk melebar. Ujung moncong runcing atau tumpul, cantus rostalis tak jelas. Lore dan pipi miring kebawah, antara mata dan tulang rahang atas terdapat alur sempit. Lipatan supra timpani yang membujur dari bagian belakang mata melalui bagian atas gendang telinga menuju ke aksila dalam bentuk lengkungan. Di antara bagian belakang kedua matanya terdapat lekuk yang tak jelas. Membran timpani sebagian tersembunyi di bawah lipatan kulit dari belakang mata sampai memotong bagian tympanum. Pada kelopak mata atas bagian belakang terdapat bintil-bintil, sedangkan daerah okspital bersifat halus. Pada tungkai depan, ujung jari berbentuk bulatan kecil, secara berurutan jari ketiga relatif lebih panjang dari jari pertama, keempat dan jari kedua.. Tungkai belakang berselaput renang penuh, ujung jari-jari berakhir dengan cakram kecil. Selaput renang antara jari kaki keempat dan kelima berpadanan tinggi dengan subartikular ketiga dan agak cekung. Secara berurutan jari kaki keempat lebih panjang dari pada jari ketiga, kelima, kedua dan jari pertama. Tuberkel tarsal sebelah medial besar dan memanjang, sedangkan tuberkel subatikular berbentuk bulat atau lonjong. Kulit halus, warna kulit pada bagian atas kepala dan punggung coklat terang, kelabu hitam sampai hitam dengan bercak hitam maupun coklat. garis loreal yang membujur dari hidung sampai mata tidak pernah dijumpai. Garis di antara kedua mata tidak jelas. Tanda huruf $\mathrm{W}$ pada bagian dorsal yang terdapat diantara kedua tungkai depan kadang-kadang terlihat dengan jelas, kadang-kadang tidak jelas. garis punggung yang membujur dari bagian antara telinga sampai dubur tidak pernah dijumpai. Permukaan ventral kepala berpigmen. Bibir sering dengan bercak gelap atau aris vertikal (Gambar 4).

Pada bagian lengan bagian atas kaki depan terdapat lorek tak teratur. Pada bagian dorsal paha terdapat lorek yang tak teratur, sedangkan di bagian belakang terdapat totol yang tak teratur. Pada betis dan tapak tungkai belakang terdapat lorek. Permukaan bawah tungkai belakang berwarna kuning pucat atau orange pucat seharusnya atau dengan bercak coklat. 


\section{KESIMPULAN}

Berdasarkan penelitian yang telah dilakukan, maka dapat diambil kesimpulan sebagai berikut:

1. Jenis katak yang biasa ditangkap untuk diperjual belikan penduduk di Sumatera Barat adalah jenis katakFajervarya limnocharis, Limnonectes blythii, Ranae erytharaea, dan Rana chalconata (Schlegel) dan Limnoneces sp

2. Jenis katak yang paling melimpah ditemukan adalah jenis Fajervarya limnocharisdi daerah Pasaman dan Painan, Rana erytharaea, dan Rana chalconatadi daerah Pasaman dan Painan. Sedangkan yang paling sedikit ditemukan adalah jenis Limnonectesblythiidi Sijunjung, Pasaman dan Mentawai serta Limnonectessp di Pasaman dan Painan

Dari penelitian yang telah dilaksanakan dapat disarankan hal sebagai berikut :

1. Mengingat katak merupakan salah satu komoditi ekspor dan sebagai mata pencaharian penduduk, maka diperlukan upaya pembudidayaan karena jenis katak yang ukuranya lebih besar keberadaanya mulai berkurang yaitu jenis katak Limnonectes blythii

2. Penelitian ini perlu dilanjutkan dengan penelitian lebih mendalam kepada keanekaragaman genetik mengingat beberapa jenis sangat jarang ditemukan dan menganalisis hubungan filogenetik di antara dan di dalam spseies itu ditemukan serta kemungkinan upaya konservasi menghindari kepunahan keaanekaraga,man jenis yang sudah mulai langka serta pengaturan ukuran penangkapan.

\section{DAFTAR PUSTAKA}

Campbell, N.A., J.B. Reece, L.G. Matchell. 2003. Biology jilid III. Jakarta: Erlangga.

Djong, T. H., D. I. Iskandar dan D. Gusman. 2010. Hubungan Filogenetik Spesies Limnonectes (Ranidae: Amphibia) Asal Sumatera Barat dan Asal Asia Tenggara Berdasarkan gen 16S Ribosomal RNA. Makara Sains. Vol. 14. No. 1 April 2010:79-87 , M. Matsui., M. Kuramoto., D. M. Belabut., Y. H. Sen., M. Nishioka and M. Sumida. 2007. Morphological Divergencce, Reproduktive Isolating Mechanisme, and Moleculer Phylogenetic Relationship Among Indonesia, Malaysia, and Japan Population of Fejervarya limnocharis oplex (Anura, Ranidae) Zoological Sciens 24: 1197-1212 
Duellman, W. E. and L. Trueb. 1994. Biology of amphibian.The Johns Hopkins University Press. Baltimore 670. pp. 1993. Amphibian Species of the World: Additions and Corrections. Univ Kansas Publ. Mus. Nat. Hist. 21:1-372.

Hellen, Kurniati. 2006. The Amphibians Species In Gunung Halimun National Park, West Java, Indonesia: 107 - 120. Research Center for Biology, Indonesian Institute of Sciences(UPI),Widyasatwaloka Building, Jalan Raya Cibinong Km 46,Cibinong 16911, West Java, Indonesia.

Inger, R. F., and D. T. Iskandar, 2005. A Collection of Amphibian from WEST Sumatera, "Whith Description of New Species of Megophrys (Amphibia: Anura. The Rafles of Zoology 53(1): 133-142

Iskandar, D. T and W.R. Erdelen. 2006. Conservation of Amphibians and Reptiles in Indonesia: Issues and Problems. Amphib. Reptile Conserv. 4(1):60-93 132 hal. 1998. Amfibi Jawa dan Bali. 1. Puslitbang Biologi-LIPI. Bogor.

Islam, M. M., Khan, M. M., Tjong, D. H., Alam, M. S., \& Sumida, M. (2008). Genetic differentiation of the Fejervarya limnocharis complex from Bangladesh and other Asian countries elucidated by allozyme analyses. Zoological science,25(3), 261.

IUCN (2004), Conservation International, and NatureServe. Global Amphibian Assessment. www.globalamphibians.org

Kusrini, M. D. and R. A. Alford. 2006. Indonesia's exports of frogs' legs. Traffic Bull. 21(1): 13-24.

M. D., A. Fitri, H. Utama, D. M. Nasir, D. Ardiansyah, V. Lestari and R. Rachmadi. 2005. Project 202404: Ecology And Conservation of Frogs of Mount Gede Pangrango National Park. Bogor, Institut Pertanian Bogor: 23 hal. , M. D., A. Mardiastuti and A. Fitri. 2003. Promoting Frog ConservationThrough Environmental Education And Research Experience: Pilot Project in West Java, Indonesia. Dalam: M. D. Kusrini, A. Mardiastuti And T. Harvey (Eds) Prosiding Seminar Hasil Penelitian Konservasi Amfibi dan Reptil di Indonesia. Bogor, 8 Mei 2003. Bogor, Departemen Konservasi Sumberdaya Hutan.Institut Pertanian: 45-51.

Sugiri, N. 1979. Studi Beberapa Aspek Biologi Katak Batu di Beberapa Wilayah dan Kedudukan Taksanya. Program Pascasarjana IPB Bogor

Van Kampen, P. N. 1923. The Amphibia of the Indo-Australian Archipelago. E. J. Brill,Ltd.Leiden. 
Lampiran: Gambar jenis katak yang di perjualbelikan di Sumatera Barat, Indonesia

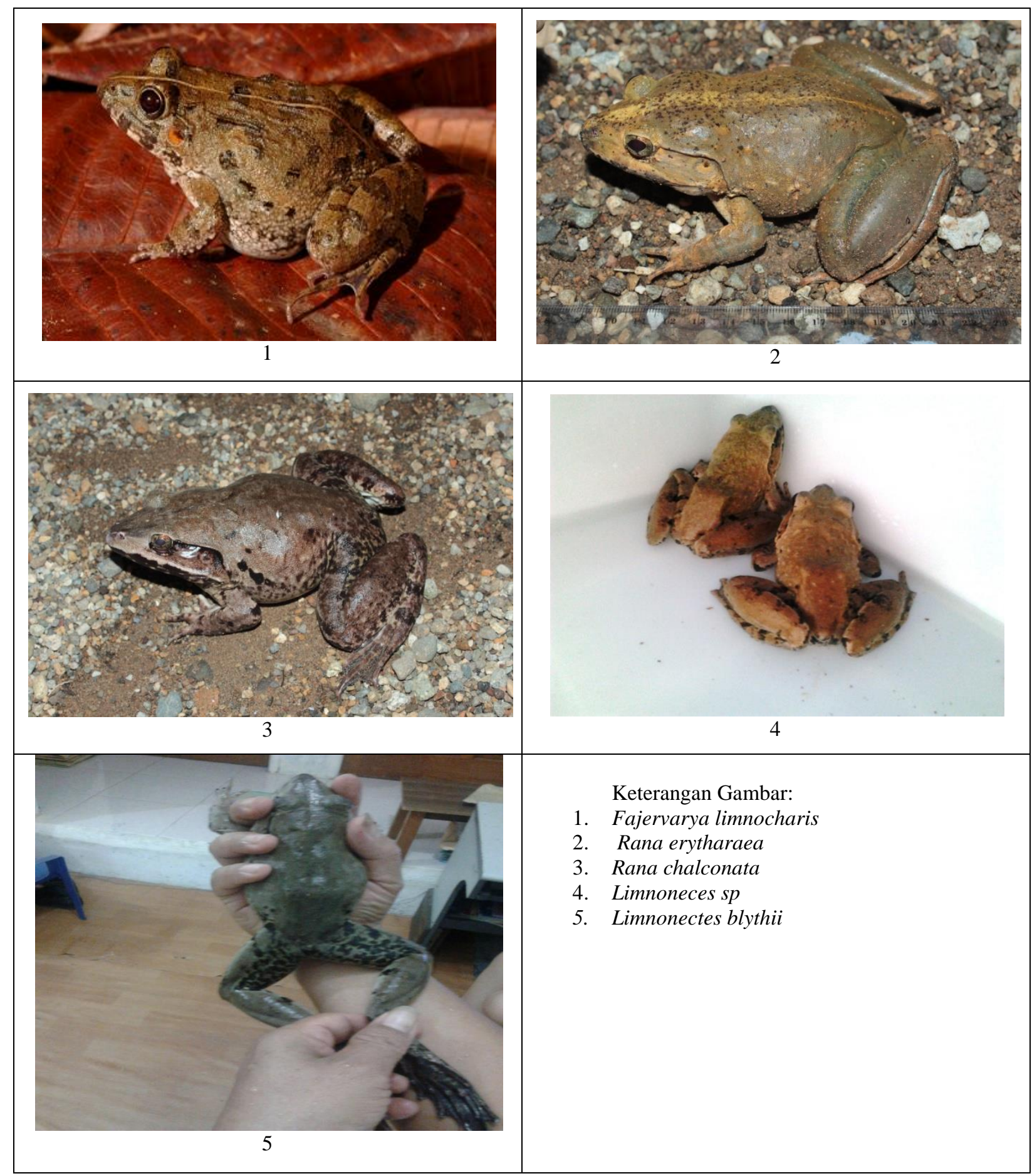

